\title{
Hard water and old food. The freshwater reservoir effect in radiocarbon dating of food residues on pottery
}

\author{
Bente Philippsen \\ Aarhus AMS Centre, Department of Physics and Astronomy, \\ Aarhus University/Museum Lolland-Falster, Rødbyhavn, DK \\ bphilipp@phys.au.dk
}

\begin{abstract}
This paper discusses the problem of the freshwater reservoir effect in the radiocarbon dating of different sample materials, in particular food crusts on pottery. Charred food residue can be used to directly date of the use of the pottery. However, this material is highly complex, which can lead to various dating errors.
\end{abstract}

IZVLEČEK - V članku predstavljamo problem sladkovodnega 'rezervoar učinka' pri radiokarbonskem datiranju različnih materialov, še posebno zoglenelih ostankov hrane na lončenini. Ti se lahko uporabijo za neposredno datiranje rabe keramičnih posod. Ker je njihova sestava zelo kompleksna, lahko pride do napak pri datiranju.

KEY WORDS - radiocarbon dating; freshwater reservoir effect; hardwater effect; pottery; food crusts; food residues

\section{Introduction}

Charred food residues on prehistoric pottery can be used in the direct radiocarbon dating of the use of the pottery. However, this material is highly complex, which can lead to different dating errors. Especially reservoir effects have to be taken into account. The freshwater reservoir effect is of particular concern due to its potentially large order of magnitude and high degree of variability. Different biomolecular methods can be used to discern the former contents of the pottery, but not all of them are equally well suited to predict reservoir effects in food crust dating.

In this paper I discuss the problem of the freshwater reservoir effect in radiocarbon dating of different sample materials, in particular food crusts on pottery. I will elaborate on this topic based on my own research (e.g., Philippsen 2012), but try to draw some more general conclusions and suggest guidelines for radiocarbon dating of food crusts.

\section{The freshwater reservoir effect}

The carbon concentration in freshwater systems, lakes and rivers, can potentially be much lower than the carbon concentration of the atmosphere. Radiocarbon dating of materials originating in the aquatic environment can therefore lead to spurious, too high ages - the so-called freshwater reservoir effect (FRE). The principle of radiocarbon reservoir effects is explained in Figure 1. Usually, we assume that all living materials are in ${ }^{14} \mathrm{C}$ equilibrium with the atmosphere (black curve). The ${ }^{14} \mathrm{C}$ concentration of the sample is measured (in this example, it is measured to $50 \%$ of the original concentration), and the radiocarbon age of the sample can be read from the graph. However, aquatic samples can have a lower ${ }^{14} \mathrm{C}$ concentration to begin with. In Figure 1, this is exemplified by a fish that only has $80 \%$ of the ${ }^{14} \mathrm{C}$ concentration of contemporaneous terrestrial samples. After its death, its ${ }^{14} \mathrm{C}$ concentration decreases according to the exponential decay law (the blue curve). When a radiocarbon concentration of $50 \%$ 
modern is measured in this case, the blue curve should be used to read off the age which is significantly lower than the $\mathbf{5 7 3 0}$ years one would read from the graph when being unaware of the reservoir effect. The difference between the radiocarbon age of the aquatic sample and the contemporaneous terrestrial sample is called 'reservoir age', or 'reservoir offset'.

The risk of a freshwater reservoir effect was recognized already in the early years of radiocarbon dating, even before the marine reservoir effect was discussed (Deevey et al. 1954; Oana, Deevey 1960; Godwin 1951). During the last two decades, research about the FRE has intensified with the studies of

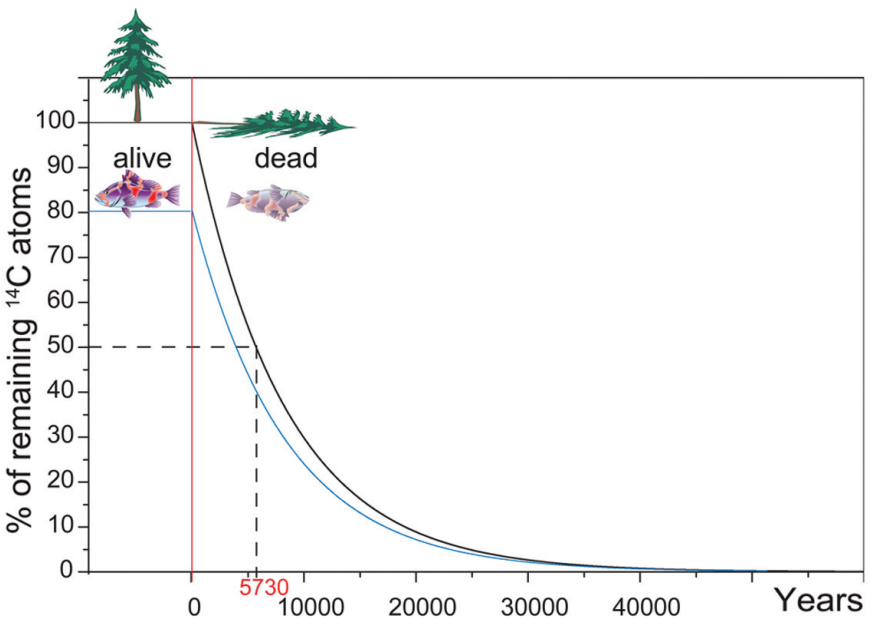

Fig. 1. The principle of radiocarbon reservoir effects. Please see the text for details. Author's own work.

FREs in human bones and food residues on pottery (Lanting, van der Plicht 1995/1996; Cook et al. 2001; Fischer, Heinemeier 2003; Shishlina et al. 2007; Smits, van der Plicht 2009; Boudin, Strydonck and Crombé 2009; Olsen et al. 2010; Philippsen 2010; Philippsen et al. 2010; Shishlina 2012).

Different mechanisms introduce 'old' carbon into lakes and rivers. The most important mechanism is the dissolution of carbonate minerals, leading to hard water and thus the 'hardwater effect'. Other mechanisms include the mineralisation of old organic matter, long residence time in aquifers, or $\mathrm{CO}_{2}$ from volcanic activity.

\section{The hardwater effect}

Dissolved inorganic carbon, DIC, is the basis of the aquatic food chain, as it is photosynthesized by the aquatic vegetation. DIC comprises dissolved carbonate, bicarbonate and $\mathrm{CO}_{2}$. It can be formed through the following process: rainwater seeps through the root zone, taking up $\mathrm{CO}_{2}$ from decaying vegetation (which has fairly recent radiocarbon ages and $\delta 13 \mathrm{C}$ values around $-25 \%$ ). The resulting carbonic acid can dissolve carbonate minerals, if present (which are infinitely old, ' $14 \mathrm{C}$ dead', and have ${ }^{13} \mathrm{C}$ values around $0 \%$ ). In summary, the reaction is:

$$
\mathrm{CaCO}_{3}+\mathrm{H}_{2} \mathrm{O}+\mathrm{CO}_{2}=\mathrm{Ca}_{2}{ }^{+}+2 \mathrm{HCO}_{3}{ }^{-}
$$

Thus, for each carbon atom from root zone $\mathrm{CO}_{2}$, one carbon atom from dissolved carbonate is added to the water. The resulting reservoir age can therefore be one half-life of radiocarbon (5730 years) at maximum. Typically, though, reservoir ages will be lower even in very carbonate-rich water, due to $\mathrm{CO}_{2}$ exchange with the atmosphere. The $\delta^{13} \mathrm{C}$ values of water DIC depend also on the $\delta^{13} \mathrm{C}$ values of the carbon sources and their relative contributions. Figure 2 illustrates the mechanisms and the resulting $\delta 13 \mathrm{C}$ values.

The FRE is therefore correlated with the carbonate concentration (alkalinity, or water hardness (Keaveney, Reime 2012)). However, the hardwater effect is not the only FRE. Other mechanisms can cause high freshwater reservoir offsets (FR0) as well. Therefore, low alkalinity does not necessarily indicate the absence of an FRE.

\section{Other causes for FREs}

There are several sources of old carbon in lakes and rivers, beyond the hardwater effect. Therefore, even carbonate-free groundwater and surface water can have high FROs. In lakes, these can be caused by slow $\mathrm{CO}_{2}$-exchange with the atmosphere due to a large depth-to-surface ratio, good wind protection or extended periods of ice cover (Håkansson 1976; Björk, Wohlfarth 2001). Old groundwater (due to long residence times in the aquifer) can increase the FRO as well as the inflow of glacier meltwater containing old $\mathrm{CO}_{2}$ or geothermal water and water containing $\mathrm{CO}_{2}$ from volcanic activity (Sveinbjörnsdottir 1992; Boaretto et al. 1998). Mineralisation of old organic matter is another mechanism that introduces ${ }^{14} \mathrm{C}$-depleted carbon into the water (Boaretto et al. 1998).

Reservoir ages measured in two Northern German rivers illustrate those mechanisms. The river with the higher alkalinity, the Trave River, has, contrary to expectation, a lower reservoir age than the lessalkaline Alster River. The Alster originates in a spring 


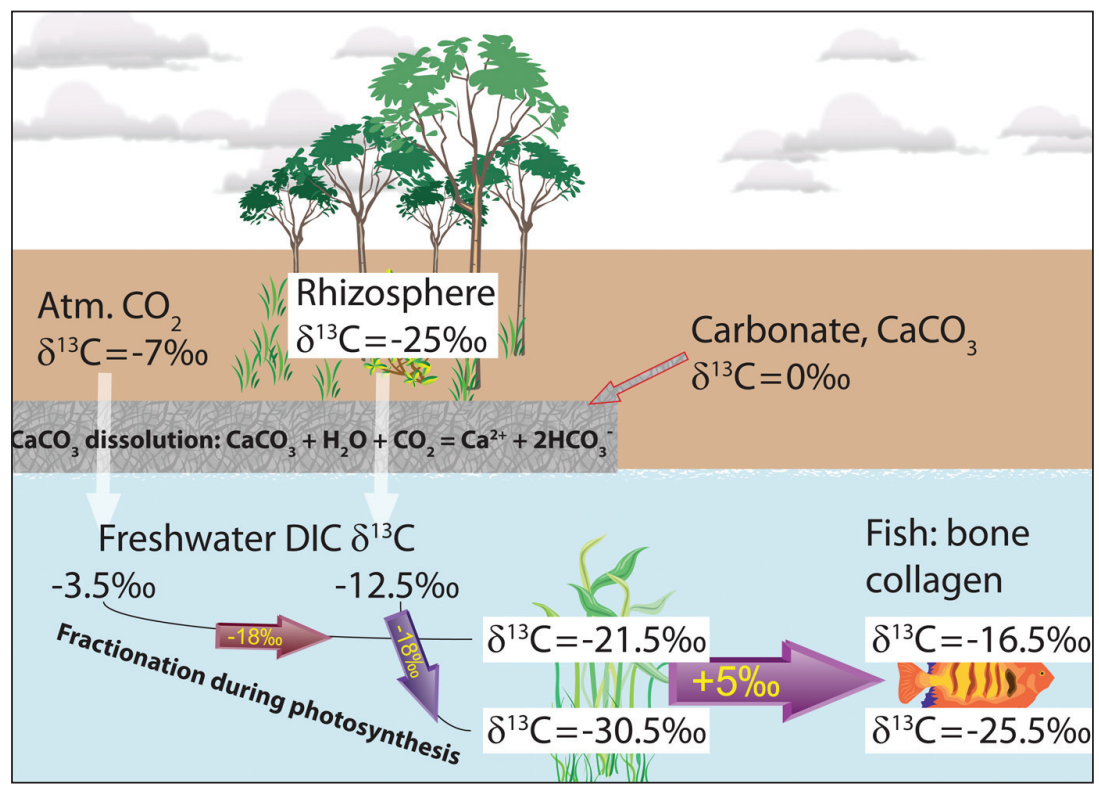

Fig. 2. Carbonate dissolution, fractionation processes in a freshwater system, and resulting $\mathbf{\delta}^{13} \mathrm{C}$ values. Author's own work.

fen, which possibly introduces old organic carbon. Furthermore, the Trave flows through a shallow lake, which lies before the sampling locations. Therefore, $\mathrm{CO}_{2}$ exchange between water and atmosphere is possible, which lowers the reservoir age (Philippsen, Heinemeier 2013). Figure 3 shows the effect of different carbon sources on the reservoir age and $\delta^{13} \mathrm{C}$ values of the water DIC. Fossil carbonate and old organic matter $\mathrm{CO}_{2}$ increase the reservoir age, while atmospheric $\mathrm{CO}_{2}$ and root zone $\mathrm{CO}_{2}$ have young or negligible radiocarbon ages. The decay of organic matter, both old organic matter and recent organic matter in the root zone, lowers the DIC $\delta^{13} \mathrm{C}$ values. Fossil carbonate, in contrast, has high $\delta^{13} \mathrm{C}$ values around $0 \%$. The $\delta^{13} \mathrm{C}$ values of atmospheric $\mathrm{CO}_{2}$ are high as well, and usually vary around $-7 \%$.

\section{Freshwater reservoir effect variability} Freshwater reservoir effects can vary with time, space, and between different species or individuals from the same freshwater system. Temporal variation can be caused by long-term changes in the relief of the landscape and the development of the lake or river. But also short-term changes in the reservoir age of the water can be observed, causing the reservoir age to vary from one year to the other.

\section{Water DIC}

This short-term variability is illustrated in Figure 3, where measurements on two ri- vers, the Alster and the Trave River in Northern Germany, are summarized. The sampling localities were not many kilometres apart; however, the rivers are separated by a watershed and have different reservoir ages and $\delta 13 \mathrm{C}$ values. Within one river, the reservoir age varies by over $1000{ }^{14} \mathrm{C}$ years during the three-year study period. Much of this variation can be explained by short-term weather fluctuations. For example, the strong influence of atmospheric $\mathrm{CO}_{2}$ on the Trave values from February 2009 might be due to the fact that the ground was still frozen. Thus, any rain- or meltwater flowed directly into the river, without percolating through the root zone. For the other sampling dates, a correlation with the amount of precipitation in the week prior to sampling could be found (Philippsen, Heinemeier 2013). Large amounts of precipitation cause the reservoir age and the $\delta^{13} \mathrm{C}$ values of the water DIC to decrease. This is probably due to the fact that large proportions of this rainwater enter the rivers as surface-runoff, flowing through the root-zone. During this process, the water absorbs $\mathrm{CO}_{2}$ from the decay of vegetation. Root zone $\mathrm{CO}_{2}$ usually has the same $\delta^{13} \mathrm{C}$ values as the vegetation:

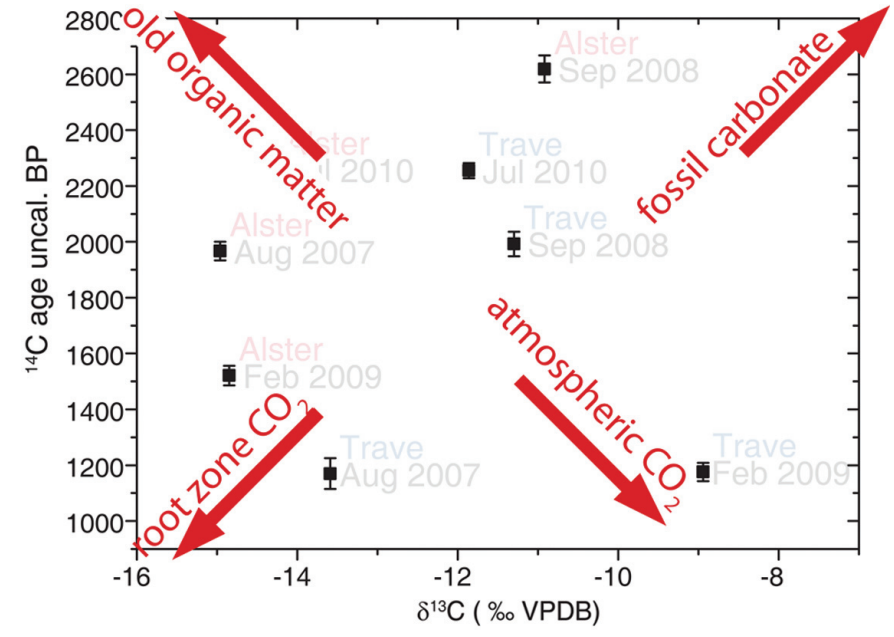

Fig. 3. Squares with error bars: ${ }^{14} \mathrm{C}$ age and ${ }^{13} \mathrm{C}$ values of water DIC from two rivers (Alster and Trave) in Northern Germany. Month and year of sampling are stated in semitransparent writing. Arrows indicate how the values would change with increasing influence of different carbon sources. Author's own work. 
the reactions during the decay of organic matter usually proceed to the end. Therefore, no fractionation is associated with this process (Galimov 1960) and root zone $\mathrm{CO}_{2}$ has $\delta^{13} \mathrm{C}$ values around $-25 \%$.

The correlations with short-term precipitation fluctuations, as well as the highly variable reservoir ages during the study period of only three years, indicate that rivers are highly complex systems in the context of the FRE. A high degree of variability is to be expected for river systems in general, especially because weather fluctuations and changes in the course of the rivers can be much larger during millennia, than during the short study period. However, it could be argued that short-term fluctuations are balanced during the growing season. Therefore, fluctuations might be smaller in plants and animals from those rivers. To test this hypothesis, several projects (including my own) have radiocarbon dated modern samples of aquatic flora and fauna.

\section{Freshwater plants}

In terms of radiocarbon dating and stable carbon isotopes, aquatic plants are very complicated organisms. The reason is the multitude of possible carbon sources for aquatic photosynthesis:

(1) DIC in the water is one possible carbon source. It occurs as different species, mainly $\mathrm{CO}_{2}$ and bicarbonate $\left(\mathrm{HCO}_{3}{ }^{-}\right)$, with different ${ }^{13} \mathrm{C}$ values $(\mathrm{Os}$ mond 1981; Emrich, Ehhalt and Vogel 1970; Andrews, Riding and Dennis 1993; Romanek, Grossman and Morse 1992). Some plants can use both species, others specialise in one of them. Depending on which species the plants specialise in, and how abundant it is at the $\mathrm{pH}$ value of the water, the plants might experience a restricted carbon pool, which limits fractionation. As mentioned above, the DIC itself can have different origins with potentially very different radiocarbon ages and $\delta^{13} \mathrm{C}$ values.

(2) Floating and emerging plants or leaves can assimilate atmospheric $\mathrm{CO}_{2}$, in addition to other carbon sources.

(3) $\mathrm{CO}_{2}$ from the rhizomes or sediment can be transported through the plant's stems and photosynthesized in the leaves or stem and leaf sheaths (Dacey 1980).
Ten samples of aquatic plants from two northern German rivers illustrate the complexity of aquatic photosynthesis. They are shown in Figure 4, which presents radiocarbon ages and $\delta 13 \mathrm{C}$ values of water DIC, aquatic plants and animals such as fish, molluscs and crayfish. The data have been published before; tables with all isotope data and radiocarbon dates can be found in Philippsen (2012) and Philippsen, Heinemeier (2013).

The radiocarbon ages of the aquatic plants range from -74 to $2273{ }^{14} \mathrm{C}$ yr BP (Fig. 4). Compared to the atmospheric ${ }^{14} \mathrm{C}$ level of the respective growing season, this results in reservoir ages between 347 and $2700{ }^{14} \mathrm{C}$ years (Philippsen, Heinemeier 2013). Currently, no factors are known which could explain the reservoir ages of the individual samples. The reservoir age is not connected to species or whether the plant grows submerged or floating; not to which river it grew in; and not to sampling season. For example, a floating plant with a reservoir age of $1300{ }^{14} \mathrm{C}$ years was collected on the same day and location as a submerged plant with a reservoir age of only $350{ }^{14} \mathrm{C}$ years.

\section{Freshwater fish and mollusks}

The great variability in radiocarbon ages can also be found on higher levels of the aquatic food chain. For this study, different samples of the aquatic fauna have been dated (orange symbols in Fig. 4). Most samples were fish bones, but also a crayfish, a snail shell and a bivalve shell, and a mallard feather were

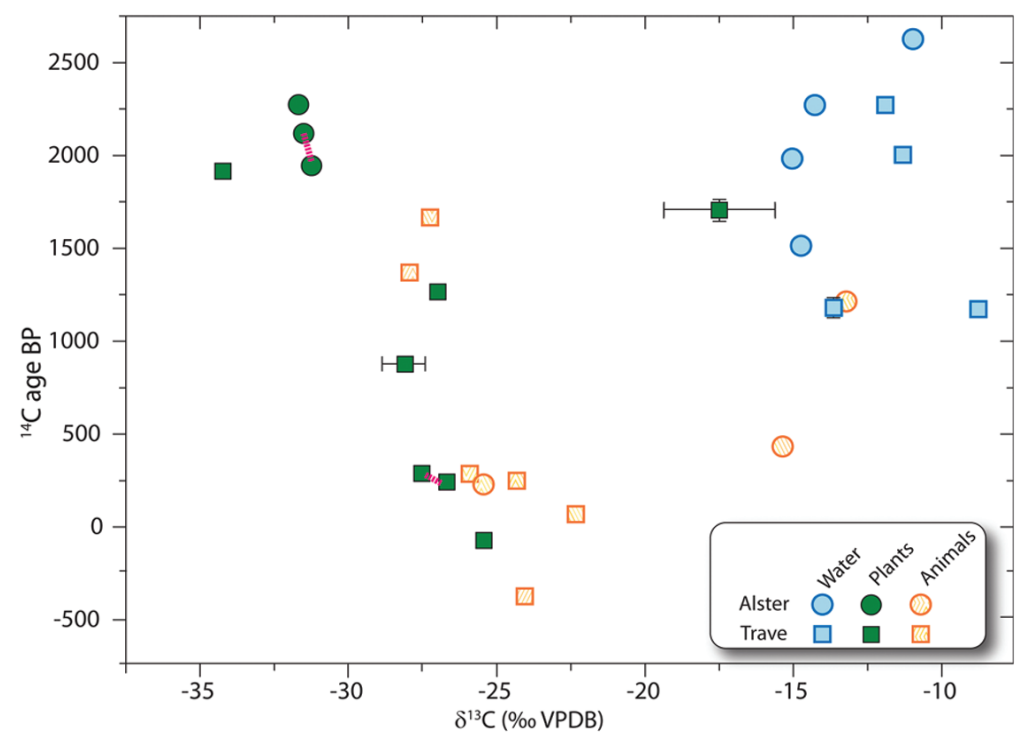

Fig. 4. Radiocarbon dates and $813 \mathrm{C}$ values of water DIC, plant and animal samples from two North German rivers, Alster and Trave. The hatched pink lines connect samples from the same individual of Nuphar lutea (leaf and petiole, respectively) (after Philippsen 2012; Philippsen, Heinemeier 2013; Philippsen et al. 2013). 
analysed. The latter had the same age as the contemporaneous atmosphere (a negative ${ }^{14} \mathrm{C}$ age in Fig. 4), so this mallard must have had a terrestrial diet. Generally, the fauna samples span about the same range as the aquatic vegetation, although none of them has as high reservoir ages as the 'oldest' plants. Correspondingly, the fauna $\delta^{13} \mathrm{C}$ values follow the same trend as the plants' values. They are shifted slightly towards more positive $\delta 13 \mathrm{C}$ values, which is to be expected when, for example, comparing a fishbone with the fish's diet. Two fauna samples have very positive $\delta^{13} \mathrm{C}$ values; these were carbonate samples of a snail shell and a bivalve shell. Generally, most plant and animal samples from these rivers follow a roughly linear relationship, where higher ${ }^{14} \mathrm{C}$-ages are correlated with more negative $\delta^{13} \mathrm{C}$-values. However, to draw any secure conclusions or to formulate a correction for the reservoir effect, more samples would be needed.

\section{Reservoir effects in food crusts on pottery}

It was hypothesized that surprisingly old radiocarbon dates on charred food residues on pottery were the result of the freshwater reservoir effect. This hypothesis was tested using a two-fold approach: on the one hand, food crusts were prepared experimentally from ingredients with known reservoir ages; on the other hand, multiple archaeological samples from two sites with hunter-gatherer pottery were analysed.

\section{Experiments}

Three series of food crusts experiments have been performed so far; the material from the third is still under analysis. Ingredients with different radiocarbon ages, as well as different carbon and nitrogen isotope values, have been prepared in the pottery. These include cereals, nuts, roots and leaf vegetables, freshwater and marine fish, bovine milk, and terrestrial herbivore meat. Different mixtures of these resources were prepared to test whether certain ingredients would dominate the food crusts.

The result of these experiments was a reference collection of food crust samples made of known ingredients. As an interesting side effect, we were able to study the suitability of the pottery for food preparation (Glykou 2012; Philippsen, Glykou and Paulsen 2012). One conclusion was that the formation of food crusts requires a lot of time and energy, especially in the case of lean fish and/or vegetables. New experiments in August 2015 will show if food crusts also can form during long-term 'normal use', i.e. food preparation without charring.

The first question was whether an ingredient with a reservoir age would form a food crust with the same reservoir age. Therefore, a food crust was made from freshwater fish, roach (Rutilus rutilus), with a reservoir age of $722 \pm 47$ years. The crust had a reservoir age of $756 \pm 41$ years, which is statistically undis-

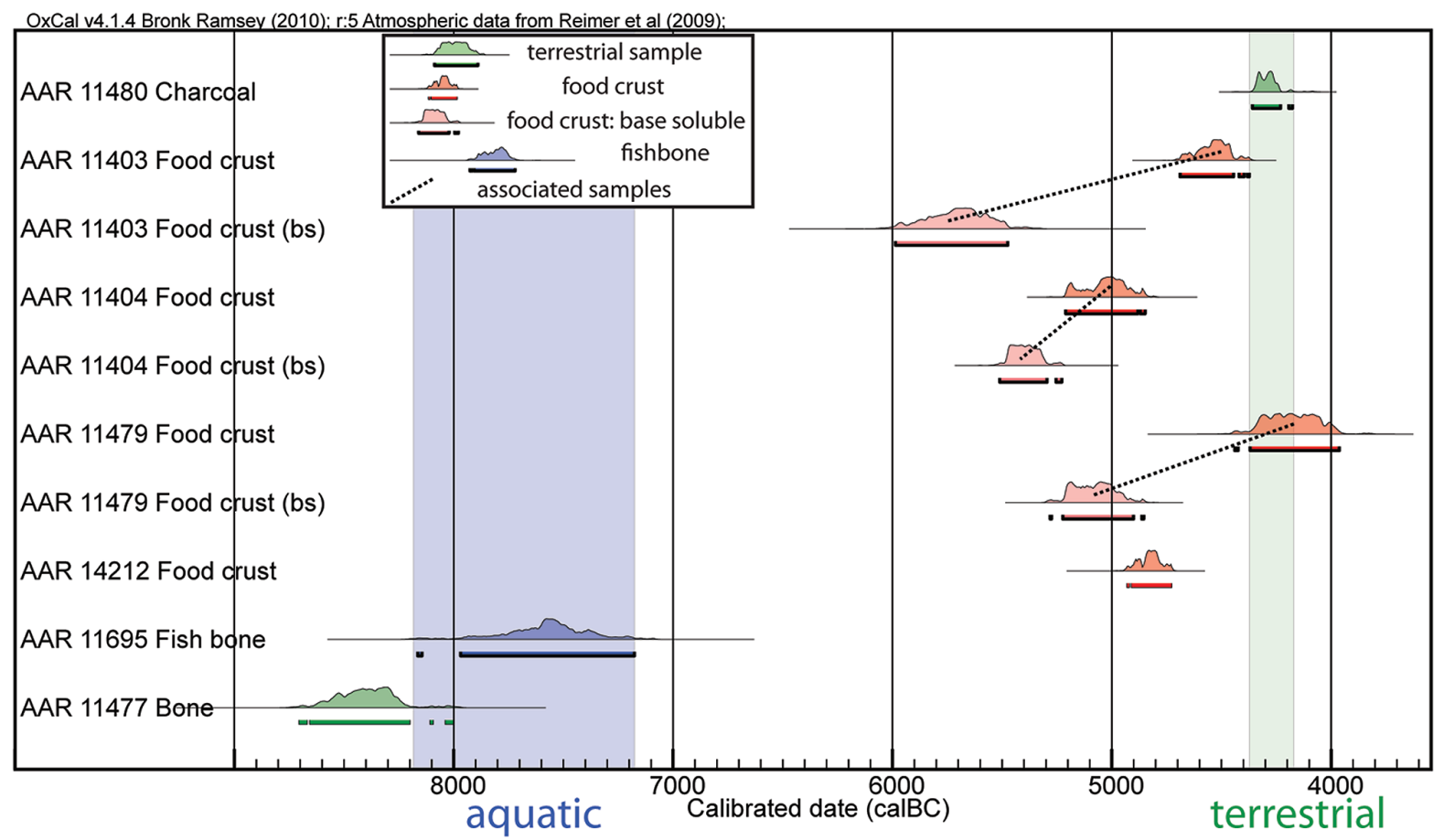

Fig. 5. Calibrated radiocarbon ages from the Ertebølle site Kayhude, Northern Germany (from Philippsen 2012). Calibrated with OxCal4 and IntCal09 (Bronk Ramsey 2009; Reimer et al. 2009). 
tinguishable from the fish's reservoir age (Philippsen 2010). The second question was whether the reservoir age of the cooking water would have an influence on the reservoir age of the food crust. Therefore, a sample of wild boar meat was cooked in river water; the water had a radiocarbon age of more than $1000{ }^{14} \mathrm{C}$ years. The wild boar food crust had a reservoir age of $-540{ }^{14} \mathrm{C}$ years. Calibrated with the bomb pulse calibration curve (Kueppers 2004), extended to present using an exponentially decreasing curve, this resulted in a calibrated age of $3 \pm 2$ years (Philippsen 2010). Therefore, we can conclude that the reservoir age of the ingredients determines the reservoir age of a food crust, irrespective of the radiocarbon age of the cooking water.
Case study: Hunter-gatherer pottery from Northern Germany

Several samples from the inland Ertebølle sites Kayhude on the River Alster and Schlamersdorf on the River Trave were radiocarbon dated to determine the local reservoir effect, the risk of reservoir effects in food crusts on pottery, and the true age of the earliest pottery in this part of Germany. The results are presented in Figures 5 and 6.

In Kayhude, the samples were collected from a relatively undisturbed stone paving (pers. comm. I. Clausen 2007). The age difference of over 3000 years between the fish and the charcoal from Kayhude is much larger than the reservoir ages that we

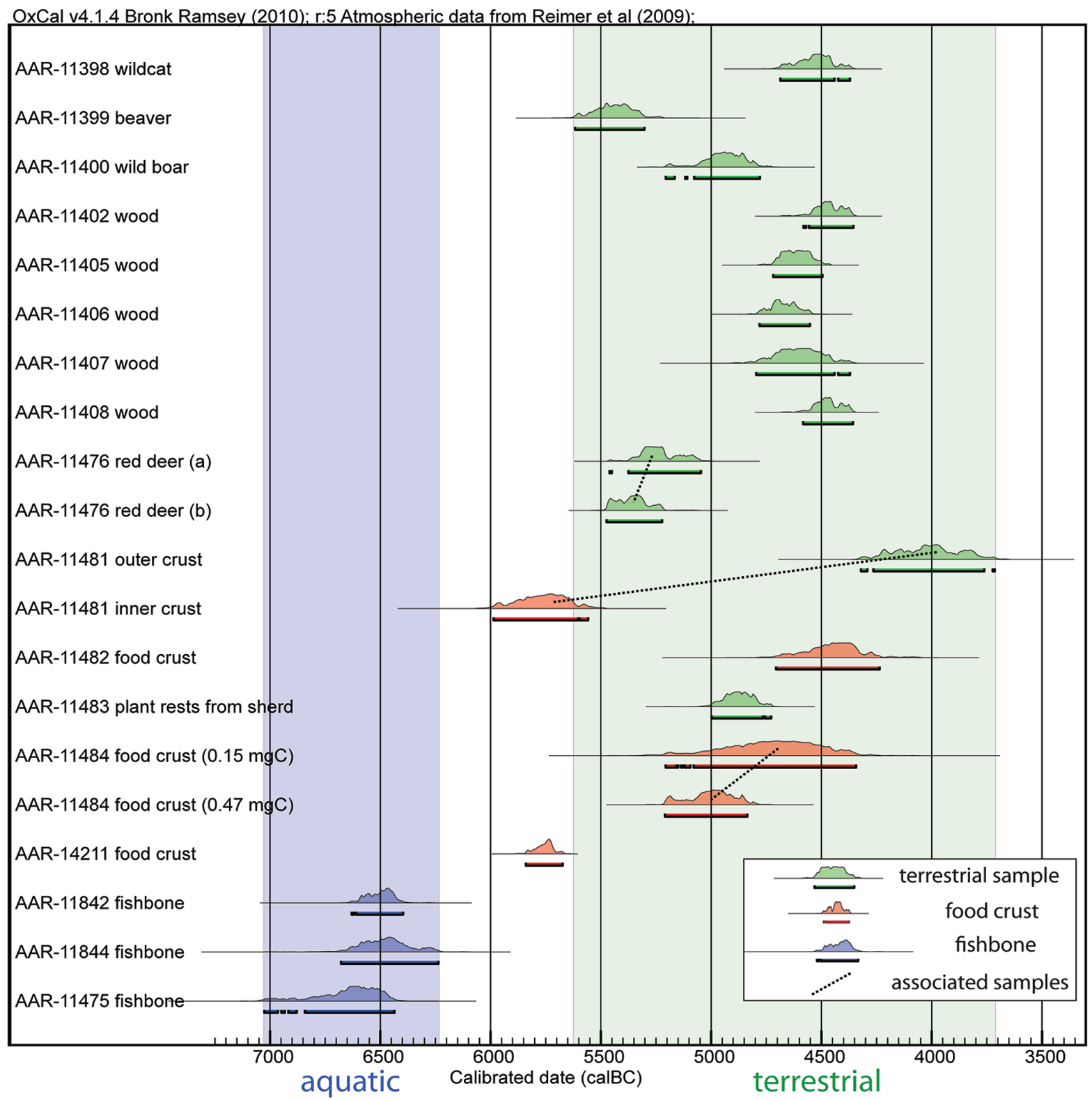

Fig. 6. Calibrated radiocarbon ages from the Ertebølle site Schlamersdorf, Northern Germany (from Philippsen 2012). Calibrated with OxCal4 and IntCal09 (Bronk Ramsey 2009; Reimer et al. 2009). 
find for modern fish, but of the same order of magnitude as the reservoir age for modern water and plants (see above). One terrestrial sample has a radiocarbon age of more than $9000 \mathrm{BP}$. This bone must be an admixture from earlier layers, as it is not only older than the other terrestrial sample from Kayhude, but also older than the oldest finds of the entire Ertebølle culture. This exemplifies that the stone paving where we found our samples cannot be regarded as totally undisturbed. Direct radiocarbon dating of the pottery is thus necessary as we cannot be sure which terrestrial samples are clearly associated with the pottery. None of the food crusts are as old as the fish bones, though. The base-soluble fraction of three food crusts has also been dated. It is likely to consist of humic acids and other degradation products from the soil, and is thus removed from the samples. Here it is older than the food crusts (Fig. 5), indicating contamination with an older soil substance. However, all purification procedures are also likely to remove some of the original food crust. The base-soluble fraction, for example, could contain fat or other base-soluble food remains. Therefore, it can be difficult to find the right balance between removing as much contamination as possible, while removing as little original food crust as possible.

The terrestrial age range of Schlamersdorf (Fig. 6) complies with earlier charcoal dates from this site (Hartz 1993). The age range of terrestrial samples is very broad. This does not mean that this site has been inhabited constantly for $1000{ }^{14} \mathrm{C}$ years. It was probably occupied repeatedly for shorter periods, as archaeological analysis indicated that the site was a hunting or fishing station. The broad terrestrial age range reveals the necessity of direct pottery dating. Two fish bone samples, AAR-11842 and AAR11844 , were associated with the red deer sample AAR11476 . The radiocarbon ages of the fish bones agree with each other, whereas they are significantly older than the red deer sample. The full freshwater reservoir effect during that period is thus more than one thousand years. Two sub-samples of the food crust AAR-11484 have been dated. The smaller sample is slightly younger. This might be the effect of a constant amount of modern contamination that enters the samples during preparation or measurement. The wildcat bone AAR-11398 and the food crusts AAR-11482 and AAR11484 had been found quite close to each other. It is therefore probable that they are contemporaneous. Their radiocarbon ages indicate a small reservoir effect in the case of AAR-11484 (the larger sample is the one dated more precisely), and no reservoir effect on AAR-11482.

\section{Methods to detect aquatic ingredients}

The formation of food crusts is a highly complex chemical process. It depends on the nutrients present in the pot and on the cooking parameters such as temperature and duration. If the cooking temperature is high enough, and the food left to cook long enough, the water will evaporate completely. Therefore, the temperature inside the pot can increase to over $100^{\circ} \mathrm{C}$. In the water-free food, proteins and some sugars combine in the Maillard reaction, while the carbohydrates caramelize. Finally, the food carbonises to form the characteristic food crusts.

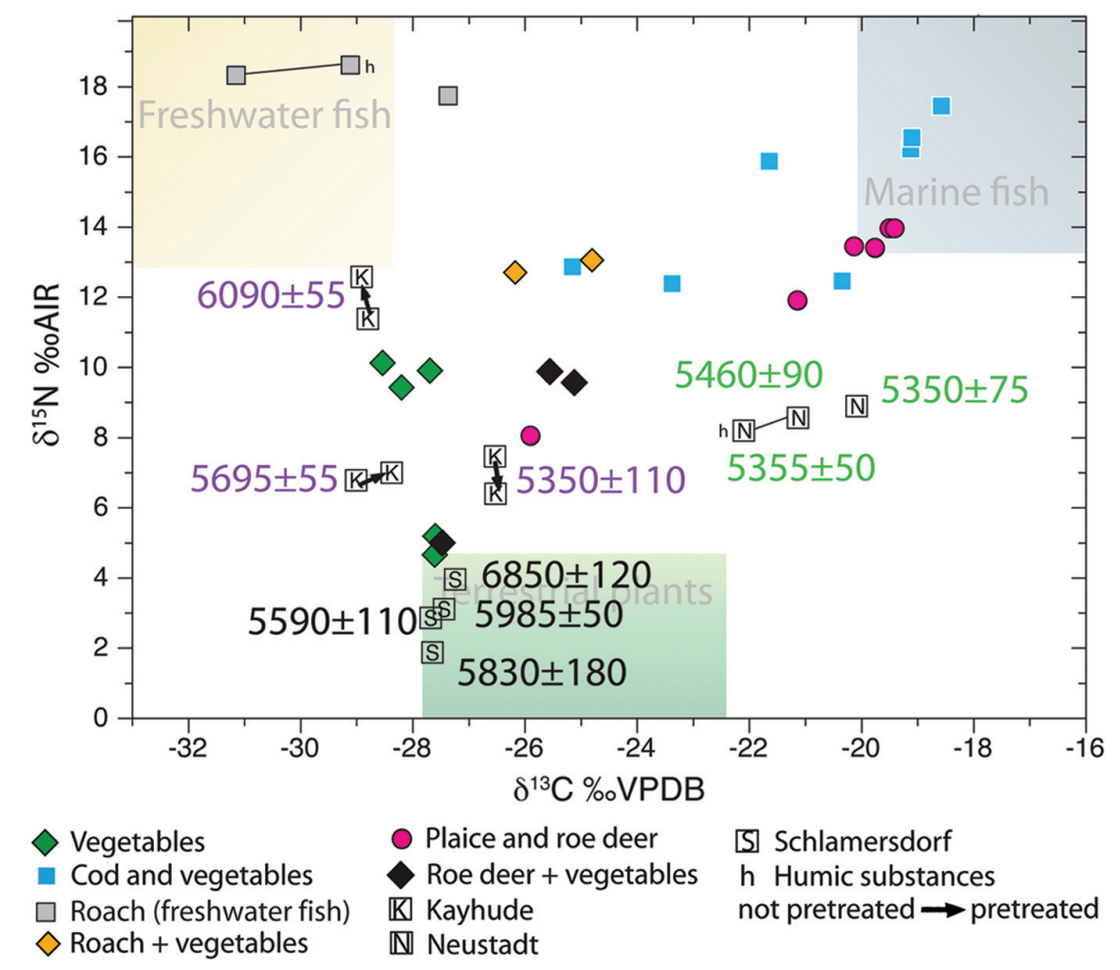

Fig. 7. $\delta^{15} \mathrm{~N}$ and $\delta^{13} \mathrm{C}$ values of experimental and archaeological food crusts. The experimental food crust values are denoted by symbols of different shape and colour, while letters mark the values of food crusts from three archaeological sites (Schlamersdorf and Kayhude, inland sites; Neustadt, coastal site; all are Ertebølle sites from northernmost Germany). 


\section{Stable isotopes}

Often, the bulk food crust material is used for radiocarbon dating (after removal of possible contaminations). Therefore, a method is needed which detects the presence and preferably abundance of aquatic ingredients in the bulk food crust. Stable isotope analysis is such a method. The $\delta^{13} \mathrm{C}$ values are in fact measured on exactly the same material as the radiocarbon age. However, $\delta^{13} \mathrm{C}$ values alone are not very accurate for the reconstruction of ingredients. Therefore, other isotopes are usually measured together with the $\delta 13 \mathrm{C}$ values, typically $\delta 15 \mathrm{~N}$. Measurements on modern samples provide reference values. Preferably, charred food crusts are analysed instead of the raw ingredients, as isotope values might change during cooking (Fernandes et al. 2014). However, in this study, only minimal changes in isotope ratios during cooking and charring were observed (Philippsen 2012). Isotope values of several experimental and archaeological food crusts are presented in Figure 7.

Interestingly, samples from the same experimental pot can have very different $\delta^{13} \mathrm{C}$ and $\delta^{15} \mathrm{~N}$ values. The ${ }^{13} \mathrm{C}$ values of mixtures of marine and terrestrial ingredients can cover a large range of up to $6 \%$. The $\delta 15 \mathrm{~N}$ ranges of some of the mixtures are of the same order of magnitude (Fig. 7). This implies that measurements on a single sherd might not be sufficient to reconstruct the former contents of the vessel. Many measurements would be necessary to get the whole picture. Furthermore, when using stable isotope measurements to correct radiocarbon dates, one should make sure to perform the measurements on the same, homogenized, sub-sample.

The expected isotope values of the experimental food crusts were calculated with the relative proportions of the different ingredients, their isotope values and their carbon and nitrogen concentrations. In some cases, the measured isotope ratios deviated clearly from the calculated expected values.
This is most likely caused by the inhomogeneity of the charred food residue, as none of the measured values was outside the range of the isotopic values of the different ingredients (Philippsen 2012).

The effect of pretreatment was tested for three archaeological food crust samples from Kayhude. The chemical pretreatment procedures remove contamination from the burial environment such as carbonates and humic substances. However, the pretreatment does not result in a systematic shift of isotope ratios (Fig. 7). Furthermore, the changes are small compared to the wide range of possible isotope values and compared to the variability of values even within one vessel. Therefore, it is concluded that the chemical pretreatment is not necessary prior to food crust isotope analysis.

The archaeological food crusts from Kayhude indicate different proportions of terrestrial and freshwater ingredients. Lower $\delta 13 \mathrm{C}$ values and higher $\delta 15 \mathrm{~N}$ values are associated with older radiocarbon ages. This agrees with our expectations, as freshwater resources are characterized by low $\delta 13 \mathrm{C}$ and high $\delta 15 \mathrm{~N}$ values. 
The $\delta 15 \mathrm{~N}$ values from Schlamersdorf would suggest a mixture of terrestrial plants and terrestrial herbivore meat. The $\delta^{13} \mathrm{C}$ values are also in the range of terrestrial plants, but in the very negative part of the range, with values around $-28 \%$. However, the very old radiocarbon ages of the food crusts from Schlamersdorf indicate a significant freshwater reservoir effect. It is therefore possible that low-trophic level aquatic food was used. Changes of isotopic ratios in the burial environment cannot be excluded as well and will be tested through the analysis of buried experimental food crusts.

In Figure 8, food crust measurements from the Femern project on the island of Lolland, Denmark, are compared to the food crust data discussed above. These data are part of an ongoing project with Carl Heron and John Meadows (Universities of Bradford and Kiel). The sherds have not been dated directly yet, but context dates and the archaeological interpretation indicate that they belong to the late Ertebølle culture and Funnel Beaker culture, i.e. the transitional phase between the Mesolithic and the Neolithic of this region. The $\delta^{13} \mathrm{C}$ and $\delta^{15} \mathrm{~N}$ measurements indicate that both terrestrial and marine resources were exploited, while freshwater resources could not be detected. The $\delta^{15} \mathrm{~N}$ values are generally lower than those of the experimental food crusts. This could be due to changes in land-use practice, e.g., manuring of modern-day vegetables, or to processes in the burial environment. Several sherds from our food crust experiments have been buried and were excavated again - they will indicate isotopic changes during burial.

Many of the analysed sherds from the Femern project belonged to one vessel, 'pot 22'. They are marked by additional small black squares in Figure 6 . Interestingly, the food crust from this pot seems to be quite homogeneous. The $\delta^{13} \mathrm{C}$ values cover a range of less than $1 \%$, while the $\delta 15 \mathrm{~N}$ values vary by about $2 \%$. The food prepared in this vessel most likely derived from terrestrial herbivores, probably mixed with plants. Ingredients with very similar isotope values were used, or the food was thoroughly mixed and homogenized during preparation.

\section{Other methods}

Several biomolecular methods are available to reconstruct vessel use and, important in the context of radiocarbon dating, detect aquatic ingredients. Probably the most widespread method is lipid analysis. Lipids can be preserved in the food crust or absorbed in the clay matrix. They indicate the presence or ab- sence of a variety of fats and can, for example, distinguish between ruminant and non-ruminant fat, marine and terrestrial fish, milk and body fat (Copley 2004; 2005; Evershed 2007; Evershed et al. 2001; Heron, Craig 2011; Craig et al. 2007; 2011). However, lipid residues and charred food crusts can potentially form from different ingredients (the food crusts from proteins and carbohydrates). Therefore, the results of a lipid analysis can only be used with caution for correcting pottery dates or identifying reservoir effects in food crusts.

\section{Reservoir effects as a source of information}

So far, we have treated radiocarbon reservoir effects as a source of error. However, when the objective of food crust analysis is more than a chronology of pottery-use, reservoir effects can be used as a source of information. When a chronological control is available, e.g., radiocarbon dates of terrestrial material from a secure context with the pottery, the reservoir effect can detect the preparation of aquatic resources in two difficult cases:

(1) When the concentration of aquatic food is very low, it will be difficult to detect with isotopic methods. This is especially the case with freshwater resources. When the freshwater reservoir effect in the study region is high, even small amounts of freshwater food will result in a measurable reservoir age.

(2) In some cases, aquatic food can have the same isotopic signature as terrestrial food. Low-trophic level aquatic food has approximately the same $\delta^{15} \mathrm{~N}$-values as terrestrial food. Furthermore, a mixture of freshwater and marine resources can result in 'terrestrial' $\delta^{13} \mathrm{C}$-values. Here, again, a reservoir effect in a 'terrestrial' food crust will indicate the preparation of aquatic ingredients.

The same principles can also be transferred to radiocarbon dating of human remains.

\section{Conclusion}

The freshwater reservoir effect is a highly complex issue. In general, the characterisation of the reservoir effect in a freshwater system requires more than a few water, plant and animal samples. Freshwater reservoir effects in a river can vary significantly on short and long timescales, spatially, and even between individuals of the same plant species, growing in the same year in the same part of the river. 
This complexity is transferred throughout the food chain, further complicated by the fact that fish can migrate within the river system or include smaller or larger proportions of terrestrial food into their diet. Food residues on pottery can be a mixture of terrestrial, marine and/or freshwater resources. Even 'terrestrial' animals can have reservoir effects, e.g., elk/moose which consume aquatic plants (Philippsen 2015) or sheep fed with seaweed (Balasse 2005). As the radiocarbon ages of the ingredients are transferred to the food crusts, they can also have very high and variable reservoir ages. In an estuarine environment, varying influence of sea water $v$ s. terrestrial run-off and freshwater will furthermore complicate the analysis of radiocarbon dates (e.g., Philippsen et al. 2013).

Therefore, samples for radiocarbon dating should be chosen wisely when the aim is to construct a chronology. Stable isotope analysis $\left(\delta^{13} \mathrm{C}, \delta^{15} \mathrm{~N}\right)$ of food crusts on pottery can indicate which of the samples contain the smallest proportions of freshwater and marine ingredients. Therefore, food crusts with the lowest risk for reservoir effects can be selected for dating. In many cases, however, reservoir effects can also be a source of information regarding the cuisine and diet of the past, or changes in the aquatic environment.

\section{References}

Andrews J. E., Riding R. and Dennis P. F. 1993. Stable isotopic compositions of Recent freshwater cyanobacterial carbonates from the British Isles: local and regional environmental controls. Sedimentology 40(2): 303-314.

Balasse M., Tresset A., Dobney K. and Ambrose S. H. 2005. The use of isotope ratios to test for seaweed eating in sheep. Journal of Zoology 266(3): 283-291.

Björk S., Wohlfarth B. 2001. ${ }^{14} \mathrm{C}$ chronostratigraphic techniques in paleolimnology. In W. M. Last, J. P. Smol (eds.), Tracking Environmental Change Using Lake Sediments. Volume 1: Basin Analysis, Coring, and Chronological Techniques. Kluwer Academic Publishers. Dordrecht: 205-245.

Boaretto E., Thorling L., Sveinbjörnsdottir Á. E., Yechieli Y. and Heinemeier J. 1998. Study of the effect of fossil organic carbon on ${ }^{14} \mathrm{C}$ in groundwater from Hvinningdal, Denmark. Radiocarbon 40(2): 915-920.

Boudin M., Strydonck M. V. and Crombé P. 2009. Radiocarbon Dating of Pottery Food Crusts: Reservoir Effect or Not? The Case of Swifterbant Pottery from Doel Deurganckdok (Belgium). In P. Crombé, M. V. Trydonck, J. Sergant, M. Boudin and M. Bats (eds.), Chronology and Evolution in the Mesolithic of North-West Europe. Proceedings of an international meeting, Brussels, May 30-June 1st 2007. Cambridge Scholars Publishing. Newcastle upon Tyne: 753-772.

Bronk Ramsey C. 2009. Bayesian analysis of radiocarbon dates. Radiocarbon 51(1): 337-360.

Cook G. T., Bonsall C., Hedges R. E. M., McSweeney K., Boroneant V. and Pettitt B. P. 2001. A Freshwater Diet-De- rived ${ }^{14} \mathrm{C}$ Reservoir Effect at the Stone Age Sites in the Iron Gates Gorge. Radiocarbon 43(2A): 453-460.

Copley M. S., Berstan R., Dudd S. N., Aillaud S., Mukherjee A. J., Straker V., Payne S. and Evershed R. P. 2005. Processing of milk products in pottery vessels through British prehistory. Antiquity 79(306): 895-908.

Copley M. S., Hansel F. A., Sadr K. and Evershed R. P. 2004. Organic residue evidence for the processing of marine animal products in pottery vessels from the precolonial archaeological site of Kasteelberg D east, South Africa. South African Journal of Science 100: 279-283.

Craig O. E., Forster M., Andersen S. H., Koch E., Crombé P., Milner N., Stern B., Bailey G. N. and Heron C. 2007. Molecular and Isotopic Demonstration of the Processing of Aquatic Products in Northern European Prehistoric Pottery. Archaeometry 49(1): 135-152.

Craig O. E., Steele V. J., Fischer A., Hartz S., Andersen S. H., Donohoe P., Glykou A., Saul H., Jones D. M., Koch E. and Heron C. P. 2011. Ancient lipids reveal continuity in culinary practices across the transition to agriculture in Northern Europe. Proceedings of the National Academy of Sciences of the United States of America 108(44): 17910-17915.

Dacey J. W. H. 1980. Internal Winds in Water Lilies: An Adaptation for Life in Anaerobic Sediments. Science 210 (4473): 1017-1019.

Deevey E. S., Gross M. S., Hutchinson G. E. and Kraybill H. L. 1954. The Natural C14 Contents of Materials from HardWater Lakes. Proceedings of the National Academy of Sciences of the United States of America 40: 285-288. 
Emrich K., Ehhalt D. H. and Vogel J. C. 1970. Carbon isotope fractionation during the precipitation of calcium carbonate. Earth Planetary Science Letters 8: 363-371.

Evershed R. P. 2007. Exploiting molecular and isotopic signals at the Mesolithic-Neolithic transition. In A. Whittle, V. Cummings (eds.), Going Over. The Mesolithic-Neolithic Transition in North-West Europe. Oxford University Press. Oxford: 141-164.

Evershed R. P., Dudd S. N., Lockheart M. J. and Jim S. 2001. Lipids in archaeology. In D. R Brothwell, A. M. Pollard (eds.), Handbook of Archaeological Science. John Wiley \& Son Ltd. Chichester: 331-349.

Fernandes R., Meadows J., Dreves A., Nadeau M.-J. and Grootes P. M. 2014. A preliminary study on the influence of cooking on the $\mathrm{C}$ and $\mathrm{N}$ isotopic composition of multiple organic fractions of fish (mackerel and haddock). Journal of Archaeological Science 50(10): 153-159.

Fischer A., Heinemeier J. 2003. Freshwater Reservoir Effect in ${ }^{14} \mathrm{C}$ Dates of Food Residue on Pottery. Radiocarbon 45(3): 449-466.

Galimov E. M. 1966. Carbon isotopes in soil $\mathrm{CO}_{2}$. Geochemistry International 3: 889-898.

Glykou A. 2012. Pointed-based pottery: An experimental approach to the manufacturing of the pottery of the Late Mesolithic in Northern Germany. The Old Potter's Almanack 17(1): 10-15.

Godwin H. 1951. Comments on radiocarbon dating samples from the British Isles. American Journal of Science 249: 301-307.

Håkansson S. 1976. Radiocarbon activity in submerged plants from various South Swedish lakes. In R. Berger and H. E. Suess (eds.), Radiocarbon Dating. Proceedings of the Ninth International Conference, Los Angeles and La Jolla. University of California Press. Berkely and Los Angeles: 433-446.

Hartz S. 1993. Inland-Ertebølle in Schleswig-Holstein. Die Fundstelle Schlamersdorf LA5, Kr. Stormarn. In D. Meier (ed.), Archäologie in Schleswig 1/1991 [Symposium Wohlde]. Christian-Albrechts-Universität. Kiel: 33-38.

Heron C., Craig 0. E. 2011. Pottery use among late foragers and early farmers in the Baltic: New molecular and isotopic investigations. In S. Hartz, F. Lüth and T. Terberger (eds.), Early Pottery in the Baltic - Dating, Origin and Social Context. International Workshop at Schleswig from 20th to $21^{\text {st }}$ October 2006. Bericht der Römisch-Germanischen Kommission, Band 89. 2008. Philipp von Zabern. Darmstadt/Mainz: 11-25.
Keaveney E. M., Reimer P. J. 2012. Understanding the variability in freshwater radiocarbon reservoir offsets: a cautionary tale. Journal of Archaeological Science 39(5): 1306-1316.

Konnerup D., B. K. Sorrell and H. Brix 2011. Do tropical wetland plants possess convective gas flow mechanisms? New Phytologist 190(2): 379-386.

Kueppers L. M., Southon J., Baer P. and Harte J. 2004. Dead wood biomass and turnover time, measured by radiocarbon, along a subalpine elevation gradient. Oecologia 141(4): 641-651.

Lanting J. N., van der Plicht J. 1995/1996. Wat hebben Floris V, skelet swifterbant S2 en visotters gemeen? Palaeohistoria 37/38: 491-519.

Oana S., Deevey E. S. 1960. Carbon 13 in Lake Waters and its Possible Bearing on Paleolimnology. American Journal of Science 258(A): 253-272.

Olsen J., Heinemeier J., Lübke H., Lüth F. and Terberger T. 2010. Dietary habits and freshwater reservoir effects in bones from a Neolithic Northern German cemetery. $R a$ diocarbon 52(2-3): 635-644.

Osmond C. B., Valaane N., Haslam S. M., Uotila P. and Roksandić Z. 1981. Comparisons of $\delta^{13} \mathrm{C}$ values in leaves of aquatic macrophytes from different habitats in Britain and Finland; some implications for photosynthetic processes in aquatic plants. Oecologia 50(1): 117-124.

Philippsen B. 2010. Terminal Mesolithic Diet and Radiocarbon Dating at Inland Sites in Schleswig-Holstein. In Kiel Graduate School "Human Development in Landscapes" (ed.), Landscapes and Human Development: The Contribution of European Archaeology. Proceedings of the International Workshop Socio-Environmental Dynamics over the Last 12,000 Years: The Creation of Landscapes (1st-4th April 2009). Universitätsforschungenzur prähistorischen Archäologie, Band 191. Dr. Rudolf Habelt GmbH. Bonn: 21-36.

2012. Variability of freshwater reservoir effects: Implications for radiocarbon dating of prehistoric pottery and organisms from estuarine environments. Unpublished PhD thesis. Aarhus University. Aarhus.

2013. The freshwater reservoir effect in radiocarbon dating. Heritage Science 1: 24.

2015. Radiocarbon dating of elk (Alces alces), an economic and symbolic resource in prehistory. In Neolithic cultures of Eastern Europe: chronology, paleoeco$\operatorname{logy}$ and cultural traditions. Materials of the International Conference, dedicated to the $75^{\text {th }}$ anniversary 
of Victor Petrovich Tretyakov, May, 12-16, 2015, St. Petersburg. Russian Academy of Sciences, Institute of the History of Material Culture. St. Petersburg: 290-294.

Philippsen B., Glykou A. and Paulsen H. 2012. Kochversuche mit spitzbodigen Gefäßen der Ertebøllekultur und der Hartwassereffekt. In U. Weller, T. Lessig-Weller, E. Hanning and B. Strugalla-Voltz (eds.), Experimentelle Archäologie in Europa - Bilanz. Unteruhldingen, Europäische Vereinigung zur Förderung der Experimentellen Archäologie e.V./ European Association for the advancement of archaeology by experiment. European Association for the advancement of archaeology by experiment 13: 33- 48 .

Philippsen B., Heinemeier J. 2013. Freshwater reservoir effect variability in Northern Germany. Radiocarbon 55 (2-3): 1085-1101.

Philippsen B., Kjeldsen H., Hartz S., Paulsen H., Clausen I. and Heinemeier J. 2010. The hardwater effect in AMS ${ }^{14} \mathrm{C}$ dating of food crusts on pottery. Nuclear Instruments and Methods in Physics Research Section B: Beam Interactions with Materials and Atoms 268(7-8): 995-998.

Philippsen B., Olsen J., Lewis J. P., Rasmussen P., Ryves D. B. and Knudsen K. L. 2013. Mid- to late-Holocene reservoir age variability and isotope-based palaeoenvironmental reconstruction in the Limfjord, Denmark. The Holocene 23(7): 1015-1025.
Reimer P. J. and 28 coauthors 2009. IntCal09 and Marine09 Radiocarbon Age Calibration Curves, 0-50,000 Years cal BP. Radiocarbon 51(4): 1111-1150.

Romanek C. S., Grossman E. L. and Morse J. W. 1992. Carbon isotope fractionation in synthetic aragonite and calcite: effects of temperature and precipitation rate. Geochimica et Cosmochimica Acta 56: 419-430.

Shishlina N. I., van der Plicht J., Hedges R. E. M., Zazovskaya E. P., Sevastyanov V. S. and Chichagova O. A. 2007. The catacomb cultures of the north-west Caspian steppe: ${ }^{14} \mathrm{C}$ chronology, reservoir effect, and paleodiet. Radiocarbon 49(2): 713-726.

Shishlina N. I., Zazovskaya E., van der Plicht J. and Sevastyanov V. 2012. Isotopes, Plants, and Reservoir Effects: Case Study from the Caspian Steppe Bronze Age. Radiocarbon 54(3-4): 749-760.

Smits L., van der Plicht J. 2009. Mesolithic and Neolithic human remains in the Netherlands: physical anthropological and stable isotope investigations. Journal of Archaeology in the Low Countries 1(1): 55-85.

Sveinbjörnsdottir Á. E., Heinemeier J., Rud N. and Johnsen S. J. 1992. ${ }^{14} \mathrm{C}$ anomalies observed for plants growing in Icelandic geothermal waters. Radiocarbon 34(3): 696703. 